\title{
Pengaruh Keterlibatan Ayah Dalam Pengasuhan Terhadap Kematangan Emosi Pada Remaja
}

\author{
SYAFIRA PUTRI RAGITA \& NUR AINY FARDANA N.*
}

Departemen Psikologi Pendidikan dan Perkembangan, Fakultas Psikologi Universitas Airlangga

\begin{abstract}
ABSTRAK
Penelitian ini bertujuan untuk mengetahui pengaruh keterlibatan ayah terhadap kematangan emosi pada remaja akhir. Definisi kematangan emosi menggunakan teori dari Katkovsky dan Gorlow. Definisi keterlibatan ayah dalam pengasuhan menggunakan teori Lamb Metode yang digunakan dalam penelitian ini adalah kuantitatif. Skala yang digunakan dalam penelitian ini adalah Inventory of Father Involvement (IFI). Kematangan emosi menggunakan alat ukur yang dibuat oleh Rizkyta \& Fardana. Analasis data diuji melalui uji statistik regresi linear sederhana. Berdasarkan hasil analisis data yang diperoleh bahwa keterlibatan ayah dalam pengasuhan berpengaruh secara signifikan terhadap kematangan emosi dengan nilai signifikansi sebesar $p=0,001$ dan nilai koefisien regresi $B=0,063$. Besaran pengaruh keterlibatan ayah dalam pengasuhan untuk menjelaskan variasi dari kematangan emosi pada remaja adalah sebesar 4\%. Dengan korelasi antar variabel bersifat positif.
\end{abstract}

Kata kunci: kematangan emosi, keterlibatan ayah, remaja.

\section{ABSTRACT}

This research aimed to examine the effect of father's involvement on emotional maturity among late adolescents. The definition of emotional maturity was from the theory of Katkovsky and Gorlow. Father involvement on this research was from theory of Lamb. The research method featured in this study is quantitative approach. There are two variables measured in this study using two different scales: translated and modified version of Inventory of Father Involvement (IFI) and emotional maturity scale from Rizkyta \& Fardana. The analysis technique used in this research was simple linier regression. Based on the results of data analysis, it was found that father involvement have significant effect on emotional maturity with significant value of $p=0,001$ and regression coeficients of $B=0,063$. Father involvement can account for $4 \%$ of the variation in emotional maturity with positive correlation between the variables.

Keywords: adolescent, emotional maturity, father involvement.

Buletin Penelitian Psikologi dan Kesehatan Mental (BRPKM), 2021, Vol. 1(1), 417-424

*Alamat korespondensi: Fakultas Psikologi Universitas Airlangga, Kampus B Universitas Airlangga Jalan Airlangga 4-6 Surabaya 60286. Surel: nurainy.fardana@psikologi.unair.ac.id

Naskah ini merupakan naskah dengan akses terbuka dibawah ketentuan the Creative Common Attribution License (CC-BY-4.0) (http://creativecommons.org/licenses/by/4.0), sehingga penggunaan, distribusi, reproduksi dalam media apapun atas artikel ini tidak dibatasi, selama sumber aslinya disitir dengan baik. 


\section{PEN D A H U L U A N}

Remaja sering mengalami perubahan pola berpikir, emosional, serta mengungkapkan penerimaan lingkungan melalui perilakunya (Putra, 2018). Berdasarkan usia, masa remaja digolongkan menjadi tiga tahap yaitu remaja awal (usia 10-13 tahun), remaja tengah (usia 14-17 tahun), dan remaja akhir (usia 18-21 tahun) (Steinberg, 2013). WHO mengungkapkan bahwa remaja berada dalam rentang usia 10-24 tahun (WHO, 2007). Menurut Santrock (2013) remaja merupakan tahap dimana individu berusia 11-18 tahun. Masa remaja merupakan masa dimana emosi tidak stabil serta perilaku dipengaruhi oleh emosi. Seperti yang diungkapkan Santrock bahwa masa remaja merupakan masa dimana jiwa penuh dengan tekanan dan gejolak emosi (dalam Natalia \& Lestari, 2015). Pada usia remaja, individu lebih memperhatikan emosinya serta mampu meningkatkan kemampuan untuk mengatasi emosinya. Remaja juga lebih mampu dalam menunjukan emosinya kepada orang lain (Santrock, 2013). Perkembangan emosional pada masa remaja melibatkan pembangunan identitas yang realistis dan koheren dalam berhubungan dengan orang lain serta belajar untuk mengatasi stres dan mengelola emosi (Santrock, 2001 dalam American Psychological Association, 2003). Sehingga pada masa remaja, emosi lebih dominan menguasai diri daripada pikiran yang realistis, hal tersebut dapat dikatakan wajar karena salah satu ciri perkembangan psikologis remaja adalah emosi yang meledak-ledak hingga sulit dikendalikan serta dapat beresiko depresi dan melakukan perilaku serta tindakan pemberontakan.

Kematangan emosi merupakan penentu yang efektif untuk membentuk kepribadian, membuat keputusan, berkelompok, membangun hubungan yang sehat, dan mengembangkan diri (Naik \& Saimons, 2014). Menurut Chaplin kematangan emosi adalah kondisi mencapai tingkat kedewasaan perkembangan emosi seseorang (dalam Paramitasari \& Alfian, 2012). Ketika seseorang telah mencapai emosi yang matang ditandai oleh pada masa remaja akhir mampu mengekspresikan emosinya melalui cara serta waktu yang tepat (Hurlock, 1999). Faktor yang mempengaruhi kematangan emosi menurut Hurlock (1999) yaitu usia, perubahan fisik dan kelenjar dari individu, dan pola asuh dari orang tua. Mampu mengkontrol emosi, mampu memahami diri sendiri, berpikir sesuai realita, serta mempu mengungkapkan emosinya pada waktu yang tepat merupakan tanda bahwa seseorang telah mencapai emosi yang matang (Ghosh, 2019). Namun, sebuah penelitian dari Jobson (2020) mengungkapkan bahwa 74\% remaja memiliki tingkat ketidakmatangan emosi yang tinggi. Remaja yang belum mencapai kematangan emosi, maka berpotensi tidak dapat mengendalikan emosinya secara efektif. Menurut Goleman (2016 dalam Dewi \& Kristiana, 2017) perilaku remaja yang tidak mampu mengendalikan emosinya akan berpotensi menimbulkan perilaku negatif yaitu agresifitas. Sebuah penelitian yang dilakukan di SMPN 9 Banda Aceh dimana meneliti pelaku bullying mengungkapkan 80.65\% pelaku bullying memiliki kematangan emosi yang rendah (Maryam \& Fatmawati, 2018). Hal ini tentu saja dapat menghambat hubungan sosial antar individu.

Orang tua berperan penting dalam emosi remaja, baik memberikan efek positif pada emosi individu remaja tersebut maupun efek negatif. Hal ini menunjukkan bahwa peran orang tua sangat penting bagi remaja (Unayah \& Sabarisman, 2015). Remaja yang memiliki komunikasi efektif dengan kedua orang tua cenderung jarang memiliki masalah serius. Remaja yang berada dalam sebuah keluarga yang lengkap serta kedua orang tua berperan dalam proses pengasuhan kemungkinan akan mampu mencapai kematangan emosi (Nashukah \& Darmawanti, 2013). Kehadiran ayah dalam kehidupan remaja sangat bermakna terutama dalam hubungan komunikasi ayah dan remaja. Menurut Lamb (2010) menjelaskan persepsi terkait peran ayah dapat berpengaruh terhadap perkembangan sosial, emosi, serta prestasi dibidang akademik. Selain itu, menurut Mischel (1961 dalam Allen \& Daly, 2007). menyatakan bahwa anak yang memiliki ayah terlibat dalam proses pengasuhan cenderung menunjukkan perilaku tidak impulsive. Ayah memiliki peran dalam perkembangan emosi remaja. Hal 
ini sejalan dengan penelitian yang mengungkapkan bahwa keterlibatan ayah dalam pengasuhan memiliki kontribusi sebesar 7,5\% terhadap kematangan emosi (Tirta \& Selviana, 2019).

Salah satu faktor penting yang mendukung keberhasilan remaja dalam menghadapi dan menyelesaikan masalahnya adalah keluarga karena keluarga merupakan lingkup sosial terdekat sebuah individu. Begitu juga dengan ayah yang menjadi sosok panutan dan berdampak positif diantaranya anak lebih mudah beradaptasi, kurangnya tingkat stress maupun frustasi pada anak (Astuti \& Puspitarani, 2013). Sebuah penelitian juga mengungkapkan peran seorang ayah selama proses pengasuhan dapat mengembangkan kemampuan problem solving serta akan mampu mengendalikan emosinya (Allen \& Daly, 2007). Selain itu, Ayah yang suportif akan memiliki efek pada perkembangan konitif dan emosional anak, sedangkan ibu hanya mempengaruhi kognitif anak (Cabrera, dkk., 2007). Berdasarkan beberapa penelitian terdahulu yang telah dijelaskan, penulis memiliki kesimpulan bahwa kehadiran ayah memiliki peran yang penting dalam pengasuhan, dimana peran serta ayah dapat mempengaruhi emosi, pengambilan keputusan, dan kemampuan sosial dari remaja. Sehingga penelitian ini memiliki tujuan yaitu untuk mengetahui apakah terdapat pengaruh keterlibatan ayah terhadap kematangan emosi pada remaja akhir.

\section{Desain Penelitian}

\section{MET ODE}

Pendekatan yang digunakan dalam penelitian ini merupakan penelitian kuantitatif, yaitu metode penelitian yang digunakan untuk meneliti populasi atau sampel tertentu, pengumpulan data menggunakan instrument penelitian, bertujuan untuk menguji suatu hipotesis (Sugiyono, 2017). Pada penelitian ini menggunakan metode pengambilan data survei. Pengambilan data dari lapangan dengan cara menyebar kuesioner. Pengambilan data secara online melalui web survey. Tujuan dari penelitian ini adalah ada tidaknya pengaruh antara keterlibatan ayah dalam pengasuhan dengan kematangan emosi pada remaja, maka dari itu perlu menguji hipotesis dengan penelitian kuantitatif. Variabel independen dalam penelitian ini adalah keterlibatan ayah dalam pengasuhan. Sedangkan variabel terikat dalam penelitian ini adalah kematangan emosi.

\section{Partisipan}

Teknik sampling dalam penelitian ini merupakan purposive sampling. Penulis menetapkan kriteria bagi partisipan yaitu berusia 18-21 tahun yang mana tergolong sebagai usia remaja akhir. Selain itu partisipan tinggal bersama ayah dan ibu. Sebelum mengisi kuesioner partisipan diberikan informed consent. Partisipan dalam penelitian ini berjumlah 283 partisipan. 74.6 persen partisipan berjenis kelamin wanita dan 25.4 persen berjenis kelamin pria.

\section{Pengukuran}

a. Skala keterlibatan ayah dalam pengasuhan penulis menggunakan The Inventory of Father Involvement (IFI) oleh Hawkins, dkk (2002) yang telah ditranslasi kedalam Bahasa Indonesia dan di modifikasi oleh Sakinah (2020) guna penyesuaian usia. Terdiri dari 35 aitem dengan 7 pilihan jawaban $(0=$ "sangat buruk", 6="baik sekali"), dengan koefisien reliabilitas yang cukup baik $(\alpha=.964)$.

b. Skala kematangan emosi penulis menggunakan skala yang di konstruksi oleh Rizkyta \& Fardana (2017) berdasarkan pada teori Katkovsky dan Gorlow (dalam Zahra, 2014). Skala ini terdiri dari 34 item dengan 5 pilihan jawaban yaitu sangat tidak setuju (STS) hingga sangat setuju (SS), dengan koefisien reliabilitas yang cukup baik $(\alpha=.904)$. 
Uji asumsi yang dilakukan dalam penelitian ini yaitu uji nomalitas, uji linearitas, dan uji heteroskedatisitas. Variabel keterlibatan ayah memiliki nilai skewness dan kurtosis berturut-turut sebesar -0,827 dan 0,203. Selanjutnya, variabel kematangan emosi memiliki nilai skewness dan kurtosis berturut-turut sebesar -0,002 dan 0,818. Sehingga dapat disimpulkan bahwa kedua variabel memiliki data yang terdistribusi secara normal apabila dipandang melallui nilai skewness dan kurtosis-nya.

Selain itu penulis juga melakukan uji linearitas, nilai signifikansi linearitas dari model regresi adalah sebesar $\mathrm{p}=0,000$. Nilai tersebut menunjukkan hasil variabel bebas yang diuji menggambarkan hubungan yang linear secara signifikan karena memiliki nilai signifikansi $\mathrm{p}<0,05$. Berdasarkan uji heteroskedastisitas diketahui bahwa tidak terdapat pola tertentu pada grafik. Sehingga dapat dinyatakan bahwa data tersebut tidak menunjukkan adanya gejala heteroskedastisitas yang menunjukkan bahwa varians dari residual suatu pengamatan ke pengamatan lain bersifat sama.

\section{Analisis Data}

Penulis melakukan beberapa uji asumsi yaitu uji normalitas, uji heteroskedastisitas, dan uji linearitas. Proses pengolahan data menggunakan SPSS 25.0 for Mac. Analisis data dalam penelitian ini menggunakan uji korelasi terlebih dahulu untuk mengetahui apakah terdapat hubungan antar variabel. Kemudian, penulis menggunakan analisis regresi linear sederhana.

\section{HAS IL PENELITIAN}

Berdasarkan hasil analisis deskriptif terdapat 283 partisipan. Nilai rata-rata keterlibatan ayah dalam pengasuhan yaitu 143,54 dengan standar deviasi 41,527. Sedangkan kematangan emosi memiliki ratarata 85,72 dengan standar deviasi 13,025. Variabel keterlibatan ayah memiliki nilai skewness sebesar 0,827 dan nilai kurtosis sebesar 0,203. Nilai tersebut menunjukkan bahwa data lebih banyak berkumpul pada rentang skor tinggi dan persebaran datanya bersifat memuncak. Variabel kematangan sosial memiliki nilai skewness sebesar -0,002 dan kurtosis sebesar 0,818. Nilai tersebut menunjukkan bahwa data lebih banyak berkumpul pada rentang skor tinggi dan persebaran datanya bersifat memuncak.

Berdasarkan hasil uji korelasi diketahui bahwa keterlibatan ayah berkorelasi positif dan cenderung sedang $(r(283)=-0,200 ; p<0.001)$ dengan kematangan emosi. Hal tersebut menunjukkan bahwa semakin tinggi tingkat keterlibatan ayah maka smakin tinggi tingkat kematangan emosi, begitu pula sebaliknya.

Penulis juga melakukan analisis regresi linier, model diketahui cocok dalam menjelaskan data $(B=76,726 ; 95 \%$ CI $[0,270 ; 1,004] ; S E=0,186 ; t=5,503 ; p<0,001)$ dan varians prediktor dapat menjelaskan 4 persen dari varians variabel dependen. Nilai tersebut menunjukkan bahwa keterlibatan ayah dapat menjelaskan 4\% dari kematangan emosi, sedangkan 96\% lainnya dapat dijelaskan melalui variabel lain yg tidak terdapat pada penelitian ini.

\section{I S K U S I}

Hasil dari penelitian ini menunjukkan adanya pengaruh signifikan dari keterlibatan ayah dalam pengasuhan terhadap kematangan emosi, dimana keterlibatan ayah dalam pengasuhan menjelaskan $4 \%$ dari kematangan emosi. Sehingga 96\% dari faktor lain yang tidak di terdapat pada penelitian ini. Adanya pengaruh keterlibatan ayah terhadap kematangan emosi dapat terjadi karena remaja mempersepsikan ayahnya secara positif sehingga menjadikan ayahnya sebagai tauladan bagi perilaku dan tindakan 
remaja (Syarifah, dkk., 2012). Ayah juga dapat memahami bagaimana kondisi lingkungan dan individu remaja. Keterlibatan ayah digambarkan sebagai waktu yang dihabiskan dengan anak dan juga keterlibatan secara tidak langsung (Lamb, 1999 dalam Hawkins, dkk., 2002).

Pada masa ini, peran kedua orang tua dalam pengasuhan merupakan salah satu faktor penting yang dapat mempengaruhi perkembangan emosi menuju emosi yang matang. Apabila salah satu figur tidak terlibat maka dapat berdampak terhambatnya anak dalam mencapai kematangan emosi, salah satunya ayah (Nashukah \& Darmawanti, 2013). Keterlibatan ayah dapat memberikan pengaruh positif terhadap perkembangan anak seperti perkembangan kognitif, emosional, sosial, serta interaksi ayah dengan anak (Lamb, 2010). Pentingnya keterlibatan ayah dalam pengasuhan menjadi salah satu pembentuk kematangan emosi yang akan meminimalisir perilaku negatif dari remaja. Faktor lain yang mempengaruhi kematangan emosi adalah pengasuhan. Selama periode ini remaja cenderung tidak stabil emosinya dan tidak menerima displin serta aturan dari orang tua. Sehingga jenis hubungan yang dibangun antara orang tua dengan remaja akan menentukan kematangan emosi (Rawat \& Gulati, 2018). Selain itu keterlibatan teman sebaya juga memiliki hubungan yang signifikan dengan kematangan emosi. Karena pada usia remaja cenderung mengenal teman sebaya berdasarkan kesamaan sifat sehingga memiliki peran yang besar (Rawat \& Gulati, 2019). Hal serupa juga diungkapkan dalam sebuah penelitian bahwa keluarga, teman sebaya, sekolah, dan masyarakat memiliki peran penting dalam kematangan emosi (Anand, dkk., 2014). Remaja merupakan masa transisi dari anak-anak ke dewasa dan memiliki kematangan emosi yang labil (Hurlock, 1999).

Hubungan antara kedua variabel bersifat positif dimana tinggi keterlibatan ayah maka kemaangan emosi juga semakin tinggi. Berdasarkan hasil analisis korelasi, diperoleh hasil bahwa terdapat hubungan signifikan antara keterlibatan ayah dalam pengasuhan dan kematangan emosi pada remaja akhir. Sebuah penelitian oleh (Syarifah,dkk., 2012) menungkapkan bahwa adanya hubungan antara kedua variabel tersebut. Kelekatan aman anak dengan orang tua juga merupakan salah satu faktor tercapainya kematangan emosi. Terdapat hubungan positif antara kelekatan aman pada orang tua dengan kematangan emosi remaja akhir di Denpasar (Natalia \& Lestari, 2015).

Kekuatan hubungan antara kedua variabel dalam penelitian ini masuk kedalam kategori sedang (Jackson, 2009). Hal ini dapat disebabkan oleh adanya faktor-faktor lain selain keterlibatan ayah dalam pengasuhan yang tidak disebutkan dalam penelitian ini sebagai penyebab matangnya emosi seseorang. Young mengungkapkan bahwa kematangan emosi seseorang dapat dipengaruhi berbagai faktor, yaitu faktor lingkungan, faktor individu, dan faktor keluarga (dalam Rizkyta \& Fardana, 2017). Menurut Ali dan Asrori (dalam Tirta \& Selviana, 2019) faktor yang mempengaruhi perkembangan kematangan emosi adalah perubahan jasmani, perubahan pola interaksi ayah, perubahan interaksi dengan teman sebaya dan perubahan pandangan luar dan pendidikan.

Penelitian ini mengungkapkan usia dan jenis kelamin tidak berhubungan secara signifikan dengan kematangan emosi. Hal ini didukung oleh penelitian yang dilakukan oleh Jobson (2020) yang mengatakan bahwa usia dan jenis kelamin tidak berhubungan dengan kematangan emosi. Walgito (2010 dalam Natalia \& Lestari, 2015) mengungkapkan usia tidak dapat dijadikan patokan bagi tingkat kematangan emosi. Kematangan emosi tidak tumbuh seiring bertambahnya usia serta ditemukan beberapa orang diusia dewasa yang masih belum matang secara emosi. Selain itu juga tidak ada perbedaan yang signifikan pada tingkat kematangan emosi ditinjau dari jenis kelamin (Wani \& Masih, 2015). 


\section{S I M P U L A N}

Berdasarkan hasil analisis yang telah dilakukan, penulis menyimpulkan bahwa terdapat pengaruh yang signifikan dari keterlibatan ayah dalam pengasuhan terhadap kematangan emosi remaja. Besaran pengaruh keterlibatan ayah dalam pengasuhan menjelaskan 4\% dari kematangan emosi.

Saran bagi peneliti selanjutnya dapat memperluas penelitian dengan menggunakan faktor lain yang mempengaruhi kematangan emosi serta menggunakan metode kualitatif untuk meneliti dinamika yang terjadi. Saran untuk ayah, perlu bekerja sama dengan ibu untuk melakukan ppengasuhan. Selain itu ayah juga perlu melakukan pendekatan serta menjalin relasi yang baik dengan remaja. Hal ini dilakukan agar tidak terjadi kesalahpahaman antara kedua belah pihak.

\section{U C A P A N T E R I MAKASIH}

Penulis berterima kasih kepada partisipan yang telah berkontribusi dalam pengisian kuesioner untuk keperluan data penelitian. Penulis juga mengucapkan terima kasih kepada pihak-pihak tidak dapat disebutkan satu persatu yang telah membantu penulis dalam penyusunan penelitian ini.

\section{DEKLARASI POTENSI TERJADINYAKONFLIK KEPENTINGAN}

Syafira Putri Ragita dan Nur Ainy Fardana N. tidak bekerja, menjadi konsultan, memiliki saham, atau menerima dana dari perusahaan atau organisasi manapun yang mungkin akan mengambil untung dari diterbitkannya naskah ini.

\section{PUSTAKA ACUAN}

Allen, Sarah, \& Daly, K. (2007). The Effects of father Involvement: An update Research Summary of the Evidence. In Parenting (Vol. 7, Issue 1). https://doi.org/10.1080/15295190709336777

American Psychological Association. (2003). Developing Adolescents. Choice Reviews Online, 40(12), 15. https://doi.org/10.5860/choice.40sup-0578

Anand, A. ., Kunwar, N., \& Kumar, A. (2014). Impact of different factors on Emotional Maturity of adolescents of Coed-School. International Research Journal of Social Sciences, 3(11), 17-19. http://pubs.iscience.in/journal/index.php/ijss/article/view/863

Astuti, V., \& Puspitarani, P. (2013). Keterlibatan Ayah Dalam Pengasuhan Jarak Jauh Remaja. Prosiding Seminar Nasional Parenting 2013, 121-131. https://publikasiilmiah.ums.ac.id/handle/11617/11011

Cabrera, N. J., Shannon, J. D., \& Tamis-LeMonda, C. (2007). Fathers' influence on their children's cognitive and emotional development: From toddlers to pre-K. Applied Developmental Science, 11(4), 208213. https://doi.org/10.1080/10888690701762100

Dewi, S., \& Kristiana, I. F. (2017). Hubungan antara Persepsi Keterlibatan Ayah dalam Pengasuhan Dengan Kecerdasan Emosional Pada Siswa Laki-Laki Kelas X Smk Negeri 4 Semarang. Jurnal Empati, 6(Nomor 4), 107-111.

Ghosh, S. (2019). Emotional Maturity Among Adolecents. The International Journal of Indian Psychology,

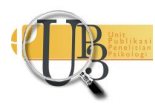




\section{4(7), 570-573. https://doi.org/10.25215/0704.065}

Hawkins, A., Bradford, K., Palkovitz, R., Christiansen, S., Day, R., \& Call, V. (2002). The Inventory of Father Involvement: A Pilot Study of a New Measure of Father Involvement. The Journal of Men's Studies, 10(2), 183-196. https://doi.org/10.3149/jms.1002.183

Hidayati, F., Kaloeti, D. V. S., \& Karyono. (2011). Peran Ayah Dalam Pengasuhan Anak. Psikologi Undip, 9(2), 1-10. https://doi.org/10.26486/psikologi.v17i2.687

Hurlock, E. B. (1999). Psikologi Perkembangan : Suatu Pendekatan Sepanjang Rentang Kehidupan. In Psikologi Perkembangan (Edisi kelima). Erlangga.

Jackson, S. (2009). Research Methods and Statistic. Wadsworth.

Jobson, M. C. (2020). Emotional Maturity among adolescents and its importance. Indian Journal of Mental Health, 7(1), 35. https://doi.org/10.30877/ijmh.7.1.2020.35-41

Lamb, M. E. (2010). The Role of the Father in Child Development. In The role of the father in child development (5th ed.). (Fifth Edit). John Wiley \& Sons, Inc. http://search.ebscohost.com/login.aspx?direct=true\&db=psyh\&AN=2010-04805-

013\&lang=es\&site=ehost-live

Maryam, S., \& Fatmawati, F. (2018). Kematangan Emosi Remaja Pelaku Bullying. Jurnal Kajian Bimbingan Dan Konseling, 3(2), 69-74. https://doi.org/10.17977/um001v3i22018p069

Naik, P. K., \& Saimons, S. K. (2014). Effect of Parenting on Emotional and Social Maturity among Adolescent. European Academic Research, 2(3), 4065-4083. https://www.researchgate.net/publication/266853137\%0AEffect

Nashukah, F., \& Darmawanti, I. (2013). Perbedaan Kematangan Emosi Remaja Ditinjau dari Struktur Keluarga. Jurnal Psikologi: Teori \& Terapan, 3(2), 93-102.

Natalia, C., \& Lestari, M. D. (2015). Hubungan Antara Kelekatan Aman pada Orang Tua dengan Kematangan Emosi Remaja Akhir Di Denpasar. Jurnal Psikologi Udayana, 2(1), 78-88.

Paramitasari, R., \& Alfian, I. N. (2012). Hubungan antara Kematangan Emosi dengan Kecenderungan Memaafkan pada Remaja Akhir. Jurnal Psikologi Pendidikan Dan Perkembangan, 1(02), 1-7. http://www.journal.unair.ac.id/filerPDF/110511131_1v.pdf

Putra, K. M. D. (2018). Pengaruh Keterlibatan Ayah dalam Pengasuhan Terhadap Penyesuaian Sosial Remaja. Universitas Muhammadiyah Malang.

Rawat, C., \& Gulati, R. (2018). Influence of Parenting Style on Emotional and Social Maturity of Adolescents. 5(1), 31-34.

Rawat, C., \& Gulati, R. (2019). Influence of Home Environment and Peers Influence on Emotional Maturity of Adolescents. Integrated Journal of Social Sciences, 6(1), 15-18. http://pubs.iscience.in/journal/index.php/ijss/article/view/863

Rizkyta, D. P., \& Fardana, N. A. N. (2017). Hubungan Antara Persepsi Keterlibatan Ayah Dalam Pengasuhan Dan Kematangan Emosi Pada Remaja. Jurnal Psikologi Pendidikan Dan Perkembangan, 6, 1-6. http://journal.unair.ac.id/filerPDF/110810241_ringkasan.pdf

Sakinah, N. (2020). Pengaruh Keterlibatan ayah dalam Pengasuhan terhadap Kecerdasan Moral Anak Usia Remaja Awal. Skripsi.

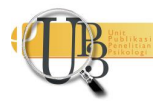


Santrock, J. W. (2013). Adolescence (Fifteenth). McGraw-Hill Education.

Steinberg, L. (2013). Tenth Edition: Adolescence (Tenth Edit). McGraw-Hill Higher Education.

Sugiyono. (2017). Metode Penelitian Kuantitatif, Kualitatif, dan R\&D. Alfabeta.

Syarifah, H., Widodo, P. B., \& Kristiana, I. F. (2012). Hubungan antara Persepsi Terhadap Keterlibatan Ayah dalam Pengasuhan dengan Kematangan Emosi pada Remaja di SMA Negeri "X." Proceeding Temu Ilmiah Nasional, 230-238.

Tirta, A., \& Selviana. (2019). Persepsi terhadap Keterlibatan Ayah dalam Pengasuhan dan Konsep Diri dengan Kematangan Emosi Siswi SMAN X Tangerang. Jurnal Psibernetika, 12, 52-57. https://doi.org/http://dx.doi.org/10.30813/psibernetika.v12i2.1671

Unayah, N., \& Sabarisman, M. (2015). Fenomena Kenakalan Remaja dan Kriminalitas. Sosio Informa, 1(200), 121-140.

Wani, M. A., \& Masih, P. A. (2015). Emotional Maturity across Gender and Level of Education. International Journal of Indian Psychology, 2(2). https://doi.org/10.25215/0202.010

WHO. (2007). Handout for Module A https://www.who.int/maternal_child_adolescent/documents/pdfs/9241591269_op_handout.pdf

Zahra, S. A. (2014). Pengaruh Kematangan Emosi dan Pola Asuh Orang Tua terhadap Altruisme pada Mahasiswa UIN Syarif Hidayatullah Jakarta. Skripsi. 